falfa regions of the West and that it is likely to prove enormously destructive to this important crop.

Prestdent Forbes: If there is nothing further on this subject, the next on our program will be by Mr. E. P. Taylor.

\title{
AN EXPERIMENT IN THE CONTROL OF CURCULIO ON PEACH
}

By Estes I'. TAYLoR, Mountain Grove, Ifo.

The greatest insect problem confronting the peach growers of the Ozarks is the prevention of injuries from the curculio (Conotrachelus nenuphar Hbst.). From reports this is also the paramount question with peach growers thronghout the whole of the Mississippi River Basin, from the northern limits of the peach on into the great peachgrowing district of the south. Nor is the middle-west and sonth alone the territory involved, for many eastern states find losses from this source quite as heavy. Making no exception for brown-rot, peachscab or other fungus disease, it may, in Missouri, excepting perhaps in those sections into which the San José scale has been introduced, be easily accorded first rank among all spraying problems of the peach grower.

This condition makes the problem today one of the greatest economic interest to peach growers and its solution in a practical way for the benefit of those interested in peach culture is one of the most productive fields now open to the economic entomologist.

The possibility of controlling curculio in apple orchards by means of arsenical sprays cannot now be doubted. This was shown to be possible in experiments conducted nearly twenty-five years ago in Illinois by Doctor Forbes, the present chairman of this Association, and at the meeting held at Philadelphia in 1905 further definite experiments were reported, showing remarkably snceessful results in this direction. Although apple growers have also employed with varying success other methods of control, the practical results to be derived from arsenical sprays has gained much favor among them within the past few years and there can be no question that spraying is the most important single operation which can be employed to reduce its injuries upon apples.

Our peach growers have, upon the other hand, entertained serious doubts as to the possibility of destroying the beetles in the peach orchard by means of arsenicals. Although here and there tried, summer spraying of peach cannot be said to be anything like a common practice. We must grant at the outset that much of the hesi- 
tancy of peach growers to use arsenicals upon peach trees has been due to their fear of doing injury to the foliage or fruit, a fear which in the past, with the use of Paris green, has been well grounded. The advent of arsenate of lead as an insecticide, with its increased adhesiveness and greater safety to the tree, makes the practicability of peach-spraying for this pest seem more promising.

An experiment conducted by the writer this season has given additional and convincing evidence that injury from the curculio can be largely prevented upon peach by proper spraying with a dilute solution of arsenate of lead, and this at a cost and with results which makes the treatment a practical operation to every peach grower in the territory where this insect occurs as a pest. Although this report is intended only as a preliminary one upon this subject and is not presented as a final recommendation to growers, it is thought that a brief account of the investigations thus far conducted and of some of the facts gathered would be timely at this meeting. The results thus far may be also of interest since the plan is, in the main, similar to one being carried out by Professor Quaintance of the Burean of Entomology.

\section{The Spraying}

The spraying experiment was conducted upon a block of 1195 sixyear-old Elberta trees belonging to the Olden Fruit Company at Olden, Missouri, and forming a portion of one of the most extensive fruit plantings in the Ozarks, comprising in all about 1,800 acres. The spraying was done with a gasoline power outfit. The spray used was Swift's arsenate of lead, costing about 12 cents per pound, and the average amount required for a very thorough application was about two gallons per tree, or only about one cent per tree per application for insecticide and only between two and three cents per tree per spray when cost of application was also included.

Upon all of the principal plats, containing from 32 to 249 trees, 2 pounds of the paste lead were used per 50 gallons, with the addition of 4 pounds of quick lime for the purpose of neutralizing any free arsenic which might happen to be present. To determine the effect of an increased amount of the lead arsenate upon the tree, a number of small plats were given varying amounts of arsenate of lead, both with and without the addition of lime. The season covered by the spraying was one of unusual rainfall. In the month of April 9.06 inches and in the month of May 10.24 inches were the recorded precipitation at the orchard, while the month of June gave 15 days in which rain fell. Not only were these conditions unfavorable for the best results but several damaging late frosts reduced the crop to a very light 
yield, a condition naturally expected to favor heavy infestation by the beetles present.

\section{The Results}

A record of the windfall peaches was secured by collection of fallen fruit under trees carefully selected at the beginning of the experiment from the central portions of each plat, so as to minimize the complications in the results otherwise likely to follow from the spreading of the beetles from one block to another. From these indicated trees the ripened peaches were picked on July 31st.

At the time of the picking of the fruit $86 \%$ of the peaches in the unsprayed block had fallen to the ground, $94 \%$ of them being wormy, as determined by cutting open each peach in malsing the examinations. Of the few remaining peaches left upon the unsprayed trees at picking time every one was found to have been injured by curculio.

In one plat which received three applications of lead arsenate, the first at the time the petals had fallen, the second thirteen days later, when the "shucks" or dried calyces were shed from the peaches, and the third eleven days later, gave $87 \%$ of the picked peaches free from curculio injury.

Another plat, which received only two applications of lead arsenate, the latter two as given in the plat just eited,-one when the "shucks" were shed and another eleven days later,-gave $89 \%$ of the picked peaches free from curculio injury.

In still another plat, which received three sprayings of arsenate of lead, one when the "shucks" shed from the peaches, another thirteen days later, and a third eleven days after the second, yielded $94 \%$ of the peaches free from curculio, and the best results of all.

It will be seen that a most remarkable improvement was secured by the spraying in the prevention of damage by curculio; a much greater difference than $I$ had expected or even hoped for at the beginning of the experiment.

A secondary beneficial effect was secured in the control of brownrot and peach scab. In the unsprayed block $61.3 \%$ of the picked peaches counted showed brown-rot infection and in practically every case the infection surrounded a puncture made by a curculio. In the plats where curculio was controlled most successfully brown-rot caused practically no damage. In one case where the curculio injury was reduced to $13.3 \%$ the brown-rot was reduced to $3.8 \%$, and in another plat where curculio was reduced to $11.4 \%$ brown-rot was reduced to $2.3 \%$.

It is almost certain that the adult curculios convey the spores of 
brown-rot upon their feet or bodies by crawling first over brown-rot "mumnties" or infected spots and then to non-infected peaches, where they may establish newly-infected areas by making new punctures or passing over old ones. This relation of the curculio to brown-rot infection, many times noted by entomologists, is worthy of further careful observations.

Arsenate of lead undoubtedly also possesses some fungicidal properties. Upon apples it has shown such action and in this experiment upon peaches a decided decrease in the amount of peach scab was noted in the sprayed portions over those left untreated.

An additional gain in improved color of fruit was also secured, which alone was enough to almost repay the cost of spraying. The peaches from the sprayed blocks where the best results had been secured in controlling curculio were of a beautiful bright red color, some very dark in fact, making them extremely attractive and adding greatly to their market value. That this color was the effect of the lead arsenate was plain, dne in part perhaps to greater exposure of the peaches to the sun by a diminution of the foliage on some trees by spray burning, buit chiefly due to direct chemical or physiological action of the arsenate of lead upon the tissue of the peach.

In some plats treated the action of the spray was severe cnough to cause burning of foliage and fruit and to cause uneasiness as to the outcome. A spray of lime water was given at one time to some plats to arrest this burning action. In some plats, where the very best results were secured in controlling the insect, some peaches showed unmistakable indications of burning upon the foliage, peaches and small twigs, though from recent observations upon these trees this injury does not appear to have been serious enough to the twigs to materially affect the prospect for fruit upon the trees the coming year.

We may sum up the results of this preliminary experiment as showing the complete possibility of the prevention of the majority of curculio injuries by arsenate of lead sprays but leaving some questions of safety to the tree from the spray still unsettled. Some important points bearing upon this were, however, brought out by the experiment, which will be valuable in the investigation continued upon the subject next year. Some of the points thought to be established and worthy of mention are:

1. The increase of lead arsenate in the spray formula increases the danger of injury'.

2. The addition of lime to lead arsenate for peach spraying reduces the danger of injury.

3. The use of lead arsenate as dilute as 2 pounds per 50 gallons with 
the addition of 4 pounds of lime is not always safe for peach spraying.

4. Early applications of lead arsenate upon peach are less likely to cause injury than those of the same formula applied later.

5 . Lead arsenate used upon peach should be practically free from uncombined water soluble arsenic and should contain a maximum amount of arsenious oxide.

\section{Spraying Suggestions}

The following is a scheme proposed for peach spraying for the spring of 1909 :

First Spray.-Immediately following the time the "husks" have dropped from the small peaches, which will be when Elbertas usually measure from $1 / 3$ to $1 / 2$ inch in diameter. Use one pound of guaranteed arsenate of lead, 2 pounds quick lime to each 50 gallons of water, applying the spray as a rather fine mist spray, using no more material than necessary to thoroughly coat the surface of every peach upon the tree. The pubescence over the peach will hold the spray and upon drying will leave the poison evenly distributed. This spray will be at about the time the first food punctures are being made.

Second Spray.-About ten days or two weeks following the first application repeat the spray, using the same formula applied as a mist and with the same thoroughness as before. This spraying will be done when numerous punctures, both food and egg, are being made.

Third Spray.-About ten days following the second give a third application in the same manner as before. At this time Elbertas will ordinarily measure 1 to $1 / 3$ inches in diameter.

These times for application being based upon development of the peach and with no reference to specific calendar dates should be applicable as guides for the proper timing of sprays for peach growers living in any section.

'The treatments, it will be seen, are suggested at a time early in the development of the peach. at the time when the first and when the majority of the food punctures are being made. The experiments this year did not indicate that arsenical sprays applied to peaches previous to the dropping of the dried calyces gave results of sufficient value to justify them. On the other hand, the destruction of the hibernating beetles early prevented egg deposition and intercepted the development of the generation emerging later. Of the three sprays recommended, the first and second are the most important. Peach trees appear to be more susceptible to injury when sprayed later than early. The time when the most adult beetles may be destroyed, fortunately for 
the fruit grower, coincides with the time when less injury is apt to be done to the trees by the spray.

This scheme of suggested treatment, it will be seen, reduces the amount of arsenate of lead from the formula used in the experiment. It seems probable, at least, that this amount of arsenical will bring about successful results. Orchardists in some sections are using only this amount of poison in their formulas against codling moth.

None but the best grades of lead arsenate should be nsed and every package purchased should be required to bear a certificate of analysis, showing quality at least up to the standard established by the national insecticide bill favored by this body for enactment before the coming session of Congress.

Mr. SLINGERLIND: What is your theory in regard to the way the poison kills? Does it kill the beetles, or don't they like the spray?

Mr. TIYIor: My belief has always been that it kills the beetles, as it is not supposed that arsenate of lead is a very strong repellent.

Mr. Quanntance: The Bureau of Entomology has been interested in this subject for several years, and I am glad to hear Mr. Taylor's paper. It confirms results we got three or four years ago, especially as to the high percentage of peaches which may be protected from the curculio attack. As to the use of arsenate of lead on peach trees, especially as to recommending its use to peach growers in the southern states, I should think it would be unwise without explanations. The effects of the lead on peach varies from year to year, and I think I have never seen the same results twice. Some years there is but little if any harm, and the next year the foliage is badly injured and much of the fruit may fall. Tests of home-made arsenate of lead show but very litthe difference. T'his question of injury has been under investigation by the Bureans of Chemistry and Entomology, and it turns out that arsenate of lead, after being applied to the trees, undergoes decomposition, and the presence of lime or its absence, while entering materially into the question, does not prevent burning. I want to urge that the recommendation as to the use of arsenicals on peach in the southern states be done with eaution and that the grower know the risk he is taking.

A Member: What time do you spray, Mr. Quaintance?

Mr. Qunn'Tnce: Just about as Mr. Taylor said, beginuing as soon as the petals are down.

Mr. TAYLOR: I would like to ask Mir. Quaintance if he has seen severe injury from the best grades of arsenate of lead where only a 
pound of lead was used, with two pounds of lime added per 50 gallons?

Mr. Qunintance: Yes.

Mr. Skinner: I have been much interested in this paper, and I think Professor Slingerland's question is rery important, as to whether the arsenate of lead is repellent, or whether it acts as a stomach poison. If it is a repellent it seems to me that it would be possible to use some other material that would have the same effect without any injury to the foliage. It has seemed to me that one of the great troubles about economic entomology is that too much reliance is placed on arsenicals, -perhaps I should not say "reliance." From the standpoint of economic entomology there are so many other chemicals that can be used. This Association has demonstrated that the men working on these lines are largely investigators, and at least have some time to devote to investigation, and these investigations of problems are the ones that to me, personally, are extremely interesting. It seems to me that that particular point is one of very great interest, whether these insects are deterred from the fact that the material that they eat is a stomach poison or whether it repels them in some other way, and I am quite impressed with this idea of the subject, and I sincerely hope that the men who have the opportunity of studying these matters will take up that point and report on it.

Mr. Hinds: I would like to ask in regard to the feeding of the plum curculio after the crop of fruit has been gathered. Is it practical to apply arsenical poisons after the crop has been removed and when the foliage is stronger than earlier in the season?

Mr. TaYLor: Mr. President, I made some jarring records this summer and found that there were very few beetles on the trees at that time. This is not conclusive evidence that some feeding might not take place, although the number of beetles secured was very small.

Mr. Schwarz: Mr. President, it is possible that there are two species of Conotrachelus that attack peaches. Many years ago, while visiting Prof. H. A. Morgan at Baton Rouge, Louisiana, he showed me specimens of Conotrachelus anaglypticus which had been bred from peaches. It would be worth while to try to ascertain the breeding habits of C. anaglypticus, as it is one of the common weevils in eastern United States. I do not think that Professor Morgan has ever published this interesting observation.

President Forbes: The next paper will be by Mr. Hinds. 